\title{
Adult polyglucosan body disease
}

INSERM

\section{Source}

INSERM. (1999). Orphanet: an online rare disease and orphan drug data base. Adult polyglucosan body disease. ORPHA:206583

Adult polyglucosan body disease (APBD) is a glycogen storage disease of adults characterized by progressive upper and lower motor neuron dysfunction, progressive neurogenic bladder and cognitive difficulties that can lead to dementia. 